\title{
Second look laparoscopyによる腹腔鏡下筋腫核出術の 術後癒着に関する検討 \\ The evaluation of adhesion formation after laparoscopic myomectomy with systemically Second look laparoscopy
}

順天堂大学産婦人科学教室

\author{
武内裕之、佐藤雄一、中野義宏
}

\section{はじめに}

腹腔鏡下手術は開腹手術に比べ、創部が小さく、 術後疼痛が少なく、入院期間が短いといったメリ ットを有する。腹腔鏡下筋腫核出術（laparoscopic myomectomy : LM) は、筋腫核摘出後の 筋層の縫合、充実性で硬い筋腫核の体外への回収 などの問題があり、これを克服するためには高度 な技術レベルが求められる。また、LMはいまだ 発展途上の術式であり、その適応と限界は施設に より一定していない"

一方、これまでのスタンダードな術式である開 腹手術による筋腫核出術では、術後癒着が高率に 発生することが報告されている。子宮創部と腸管 の癒着により疼痛やイレウスが発生し、卵管など 付属器との癒着により妊孕性が障害される。腹腔 鏡下手術は開腹手術に比べ術後癒着の発生が低い ことが報告されているが、LM後の瘉着発生状況 に関する検討は少ない。さらに、近年、様々な癒 着予防製剤が開発されているが、これら製剤の LM後の癒着防止効果に関する検討も少ない。

Second look laparoscopy（SLL）を施行して LM施行後の術後癒着の発生状況とそれにおよぼ す因子を検討した。

\section{対象と方法}

1997年 1 月から 2000 年 3 月まで115例に、既に 報告した方法 ${ }^{2}$ でLMを施行した。LMの方法は、 子宮筋層と筋腫核被膜の間に生理食塩水で希䣋し たピトレシンを局注し、針状モノポーラーで筋腫 核直上に横切開を加えて核出した。創面からの出 血は針状モノポーラーで放電止血した。縫合操作 はすべて体腔内で行い、子宮筋層は筋腫核の深さ に応じ、2/0 Vicryl弯曲針で全層縫合（結節また
は連続縫合）するか、筋層を 1 層から 4 層にZ縫 合した後、漿膜はエンドステッチ ${ }^{\mathrm{TM}}$ (オートス ーチャージャパン) でbaseball sutureまたは 2/0Vicrylで連続縫合を行った。筋層の縫合部に はフィブリン糊（ベリプラスト ${ }^{\mathrm{TM}}:$ アベンティ

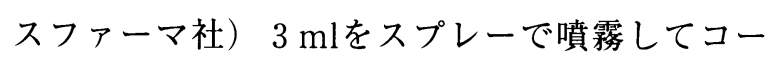
ティングした。

$3 \mathrm{~cm}$ 以上の筋腫を摘出した91例中、挙児希望 があり、同意の得られた21例にSLLを施行した。 LMの適応は不妊 10 例 $(47.6 \%)$ 、下腹部痛 3 例 (14.3\%)、月経困難 6 例 (28.6\%)、過多月経 3 例 (14.3\%)、 $5 \mathrm{~cm}$ 以上の筋腫核 14 例 $(66.7 \%)$ 、圧迫 症状 3 例（14.3\%）であった（重複例あり）。LM からSLLまでの期間は平均 $5.6 \pm 3.6$ (range : 2-18) カ月で、 3 例が全身麻酔下に $5 \mathrm{~mm}$ のスコープで、 18例がケタミンによる静脈麻酔下に $3 \mathrm{~mm}$ のスコ ープ゙ににより腹腔内を観察した。

SLL施行時には筋腫核出後の創部および付属器 の癒着の有無とその程度を観察した。子宮創部に おける癒着の程度はthe Operative Laparoscopy Study Group Classification (OLSG, 1991) ${ }^{4)}$ に基 づいて分類した（type 1：フイルム様瘉着、type 2 : 強固なまたは血管新生を伴う癒着、type 3 : 組織同士が密着した癒着)。付属器周囲癒着はthe American Fertility Society Classification (AFS, 1988) ${ }^{5)}$ によりスコアリングした。SLLに際して は、全例に8Fr.小児用バルーンを子宮内に留置し、 インジゴカルミンによる卵管色素通水検查を行 い、宮創部の状態も確認した。

統計学的処理は、 $\chi 2$ 検定、Mann-Whitney ranks sum testにより行い、 $\mathrm{P}<0.05$ 有意差あり とした。 


\section{結 果}

SLLを施行した 21 例の平均年齢は $33.0 \pm 4.3$ (range25-42) 歳で、16例（76.2\%）にGnRH agonistの術前投与が行われていた。これらの症例の 初回手術時の所見を表 1 に示す。 $3 \mathrm{~cm}$ 以上の摘 表 1 LM初回手術時の所見

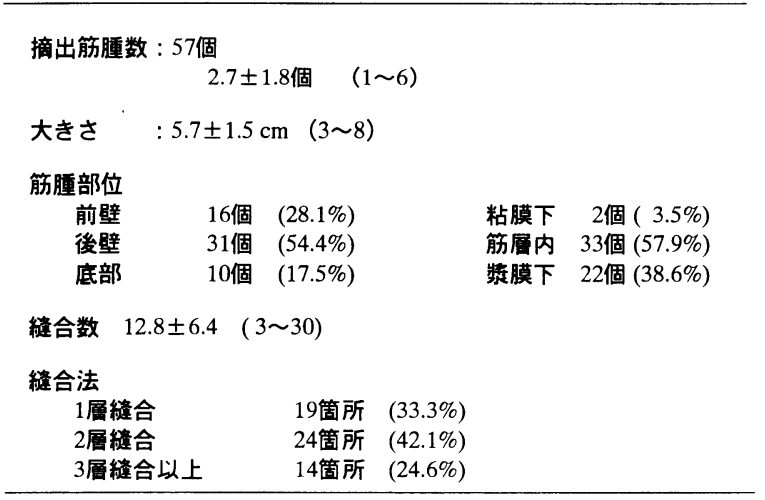

出筋腫核は 57 個で、1 人あたり $2.7 \pm 1.8$ (range 1-6）個であった。筋腫核の大きさの平均は $5.7 \pm$ 1.5 (range 3-8） cmで、筋腫摘出後はすべての部 位で最低 1 針以上の縫合を行った。筋腫部位は前 壁16個、後壁31個、底部10個であり、筋腫の深さ は粘膜下 2 個、筋層内 33 個、漿膜下 22 個（うち有 茎性 8 個）であった。連続縫合を除いた平均縫合 数は12.8 \pm 6.4 （range 3-30）針で、創面の縫合は 1 層縫合が19筒所、 2 層縫合が24箇所、 3 層また はそれ以上の縫合を行ったのが14箇所であった。

初回手術時、LM以外に同時に施行された手術 手技は、囊腫摘出術 6 例 $(28.6 \%)$ 、ダグラス窩癒 着剥離術 2 例 $(9.5 \%)$ ，付属器癒着剥離術 1 例 (4.8\%)、FTシステム 1 例 (4.8\%) であった。初 回手術時の手術時間は平均 $115 \pm 41$ (range 55225）分、出血量62 $\pm 59(10-256) \mathrm{ml}$ 、摘出筋腫 核重量81 \pm 59 （10-250）gであった。

子宮創部への術後癒着は 5 例 $(23.8 \%) 、 6$ 筒所 表 2 SLLの結果

\begin{tabular}{|c|c|c|c|}
\hline \multirow[t]{5}{*}{ 癒䍰発生： } & $5 / 21$ 例 （23.8\%） & & \\
\hline & $6 / 57$ 箇所 $(10.5 \%)$ & & \\
\hline & Type 1 (フィルム状) & ; 2 & \\
\hline & \multicolumn{3}{|c|}{ Type 2 (強固または血管新生) ; 3} \\
\hline & \multicolumn{3}{|c|}{ Type 3 (臟器どうしが密着) } \\
\hline 痹着部位： & $\begin{array}{ll}\text { 前壁 } & 0 / 16(0 \%) \\
\text { 後壁 } & 6 / 31(19.4 \%) \\
\text { 底部 } & 0 / 10(0 \%)\end{array}$ & 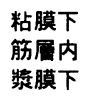 & $\begin{array}{l}0 / 2(0 \%) \\
5 / 33(15.2 \%) \\
1 / 22(4.5 \%)\end{array}$ \\
\hline 㾂屇組織： & $\begin{array}{ll}\text { 大網 } & ; 1 \text { (Type1のみ) } \\
\text { S状結腸 } & ; 5\end{array}$ & & \\
\hline 付属器周囲癒着 & $\begin{array}{l}\text { 4/ 21例 } \quad(19.0 \%) \\
5 / 42 \text { 箇所 }(11.9 \%)\end{array}$ & & \\
\hline
\end{tabular}

（10.5\%）に認められた。癒着の程度はtype1：2 例、type 2：3 例、type3：1例であった。癒着 部位はすべて後壁であり、筋層内筋腫が 5 箇所、 漿膜下筋腫が 1 箇所であった。すべての癒着部位 で 2 層以上の筋層縫合が行われていた。癒着組織 は大網が 1 箇所（type1）、他の 5 箇所はすべてS 状結腸であった。

SLL時に創部の状況が確認できたのは、type3 の癒着が認められた 1 例を除く20例であり、すべ ての症例で子宮筋層の創部は癒合閉鎖しており、 インジゴカルミンの注入で漏出がみられたり、創 部が青染したりする症例はなかった。

付属器周囲瘉着は 4 例 $(19.0 \%) 、 5$ 箇所 (11.9\%) に認められた。癒着スコアは 4 点が 3 箇 所、8 点、16点がそれぞれ 1 箇所と比較的軽度な ものが多かった。 4 例中 3 例は初回手術時に囊胞 摘出術施行例であり、LMのみを行った症例にお ける付属器周囲癒着の新生は 1 例、 1 箇所のみで あった。

LM後の癒着発生の特性を検討するため子宮創 部へのtype2以上の癒着が認められた 4 例と他の 17例の背景因子を比較したのが表 3 である。年齢、

表 3 術後癒着の有無による背景因子の比較

\begin{tabular}{|c|c|c|}
\hline & $\begin{array}{c}\text { 術後漑着 } \\
\mathrm{n}=4\end{array}$ & $\begin{array}{c}\text { 術後被着 (-) } \\
\mathrm{n}=17\end{array}$ \\
\hline 年畄 & $32 \pm 6$ & $33 \pm 3.9$ \\
\hline 内膜症合併例 (\%) & $2 / 4(50 \%)$ & $9 / 17(53 \%)$ \\
\hline 最大筋䭪核径 $(\mathrm{cm})$ & $6 \pm 1(5-7)$ & $6 \pm 2(3-8)$ \\
\hline 能腫数 & $3 \pm 2(1-5)$ & $3 \pm 2(1-8)$ \\
\hline \multicolumn{3}{|l|}{ 能腫部位 } \\
\hline 前壁 & $1(10 \%)$ & $15(31.9 \%)$ \\
\hline 後暨 & $7(70 \%)$ & $24(51 \%)$ \\
\hline 底部 & $2(20 \%)$ & $8(17 \%)$ \\
\hline 粘膜下 & $0(0)$ & $2(4.3 \%)$ \\
\hline 筋層内 & $6(60 \%)$ & $27(57.4 \%)$ \\
\hline 獎膜下 & $4(40 \%)$ & $18(38.3 \%)$ \\
\hline \multicolumn{3}{|l|}{ 手術成績 } \\
\hline 縫合数 & $14 \pm 4(8-18)$ & $13 \pm 7 \quad(4-30)$ \\
\hline 手術時間 （分） & $119 \pm 32(80-145)$ & $113 \pm 44(55-225)$ \\
\hline 出血量 （ml） & $38 \pm 15(20-50)$ & $68 \pm 64(10-250)$ \\
\hline 摘出物重量（g） & $105 \pm 94(38-245)$ & $75 \pm 65(11-256)$ \\
\hline
\end{tabular}

内膜症合併率および筋腫の数や大きさおよび存在 部位、手術成績のいずれにも有意差は認めず、瘉 着発生のリスク因子を特定することはできなかっ た。

SLL施行後 6 力月以上経過を観察し得た不妊症 例 6 例中 4 例 $(66.7 \%)$ に妊娠が成立し、うち 1 例はtype3の癒着が認められた症例である。4 例 中粘膜下筋腫を核出した 1 例に帝王切開術が施行 され、 2 例は経腟分娩し、1 例は妊娠継続中であ る。 


\section{考察}

子宮筋腫核出術は、術後癒着が最も好発する術 式であるとされてきた。Second lookによる評価 では、開腹手術による筋腫核出術後の癒着形成は 90\%以上の症例に認められると報告されている ${ }^{6) ~ 8) ~}$ が、これに対し、LM後の癒着形成は少ない（表

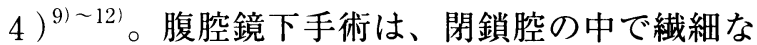
表 4 腹腔鏡下筋腫核出術瘾着に関する報告

\begin{tabular}{lccccc}
\hline 報告者 & & 症例数 & 核出部位 & 着例(\%) & 着部位(\%) \\
\hline Nezaht & $(1991)$ & 32 & 56 & - & $28(56 \%)$ \\
Hasson & $(1992)$ & 24 & - & $16(67 \%)$ & - \\
Mais & $(1995)$ & 50 & 70 & $32(64 \%)$ & - \\
\multicolumn{2}{l}{ Dubisson (1998) } & 45 & 72 & $16(41 \%)$ & $11(24 \%)$ \\
\multicolumn{2}{l}{ 今回の検討 } & 21 & 56 & $5(24 \%)$ & $6(10.7 \%)$ \\
\hline
\end{tabular}

宮内膜に向かって垂直に分岐する。すなわち子宮 筋層の血管はすべて子宮筋層を横走する。五十嵐 は、子宮筋腫核出術に際しては、これらの血管の 切断を避けるため筋層の切開は横方向に行い、縦 方向に縫合することにより、術中術後の出血を抑 えることができると報告している ${ }^{15)}$ 。われわれも この方法を採用しており、術後癒着の原因となる 出血が少なくなった可能性が考えられる。

近年、さまざまな瘉着防止剂が開発 され、術後癒着の予防に使用されてい る。われわれが使用したフィブリン糊 はベリプラスト ${ }^{\mathrm{TM}} 3 \mathrm{ml}$ であり、フィブ リノーゲン末を血液凝固第XIII因子を アプロチニン液で溶解したA液とトロ ンビン末を塩化カルシウムで溶解した B液から構成される。これを専用のフ

手術器具を用い、拡大した術野をみながら手術を 行い、かつ術野の污染や乾燥が少ないため、開腹 手術に比べ術後の癒着形成が少ないとされてい る。この事実は約10年前にいくつかの動物実験な どにより証明されている ${ }^{4.13 .14) 。}$

LM後の癒着形成率は開腹手術に比べ低いとは いえ、その発生頻度は $30 \%$ 以上と少なくない。 Dubuisson $~^{121}$ はLM後の45症例に対し、帝王切 開術や開腹手術施行時およびSLLにより72箇所の 筋腫核出部の癒着について詳細な検討を行った。 それによれば16例 $(35.6 \%) 、 12$ 箇所 $(16.7 \%) に$ 術後癒着が認められたと報告している。しかし、 45例中16例は帝王切開施行時の観察であり、SLL による系統的な観察は20例のみである。術後妊娠 が成立した帝王切開症例における評価はバイアス がかかりやすく、かれら自身帝王切開施行例16例 中癒着が認められたのはわずか 1 例 (4.5\%) であ ったと述べている。

今回の我々の検討では、術後瘉着の発生は

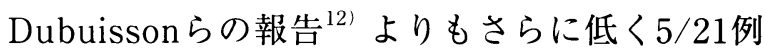
(23.8\%)、6/57箇所 (10.5\%) であった。今回施行 した症例が帝王切開症例を含まずすべて系統的に 行ったSLLによるものであること、さらに評価し た子宮創部がすべて縫合した部位であることを考 慮すると術後癒着発生率はさらに低いものと考え られる。この要因として、Dubuissonらとわれわ れのLMの術式を比較すると、筋層の切開が横切 開であること、核出術後の癒着防止にフィブリン 糊を使用していることが考えられる。

子宮筋層の血管は、子宮動脈から分岐した弓状 動脈が子宮筋層を横走し、さらに放射状動脈が子
イブリン糊スプレーチューブに接続して、子宮創 部に噴霧した ${ }^{16)}$ 。噴霧されたベリプラスト ${ }^{\mathrm{TM}}$ は、 子宮表面でA液とB液が混ざり、フィブリンとな る。形成されたフィブリン膜は、 $1 \sim 2$ 分後には ゲル状に固まって子宮創部をコーティングし、他 臓器の創部への接着のバリアーとなる。術後癒着 予防におけるフィブリン糊の有用性は、卵巣チョ コレート霟胞の腹腔鏡下摘出術後のSLL ${ }^{17)}$ や動 物実験 ${ }^{18)}$ により証明されている。MaisらはLMを 行った50例の子宮創部をInterceed ${ }^{\mathrm{TM}}$ (Eyhicon社) で被覆し、Second lookを施行し、32例（64\%） に術後癒着を認めたと報告している ${ }^{11)}$ 。今回の検 討における子宮創部への瘉着発生は $23.8 \%$ ありあ、 術後癒着防止におけるフィブリン糊の有用性が示 された。

今回の検討におけるLM後の瘉着形成のリスク 因子は、後壁に存在する筋腫、筋層内筋腫、摘出 後筋層の多層縫合であった。前壁や底部に存在す る筋腫では核出後の癒着が全く認められなかった のに対し、後壁の筋腫では6/31例（19.4\%）に瘉 着が認められた。筋腫核出術後の癒着が後壁に多 発することは諸家も指摘するところであり、また 今回の検討で癒着臓器のほとんどがS 状結腸であ ったのも同様である。また、漿膜下筋腫では $1 / 22$ 例 (4.5\%) にのみ癒着がみられたのに対し、筋層 内筋腫では $5 / 33(15.2 \%)$ に癒着が認められた。 槳膜下筋腫と異なり、筋層内筋腫では筋層の縫合 数が多くなり、創部の虚血と縫合糸の異物反応に よりフィブリンが析出し、癒着が形成されるもの と思われる。

術後付属器周囲癒着は妊孕性を障害する大きな 
因子であるが、今回の検討では 4 例（19\%）に認 められ、いずれも子宮創部に癒着を有する症例に 合併していた。強固な癒着が認められたのは 1 箇 所のみであり、他の癒着はすべてSLL時に容易に 剥離可能であった。

術後癒着の形成に関してはいまだ解明されてい ない点が多く、今回の検討でも type 2 以上の癒着 が認められた 4 例と他の17例において、背景因子 に差は認められず、癒着発生における体質的・遺

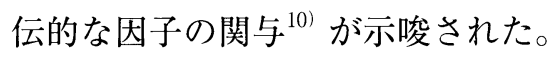

手術侵襲の小さなLMは、開腹手術に比べ術後 の癒着形成も少なく、妊孕性の温存に適している が、術後癒着の発生を減少させるためにさらなる 検討が望まれる。また、LM後のSLLは、術後癒 着の観察のみならず、子宮創部の確認にも有用で あり、妊娠成立後の分婏様式の決定に大きな役割 を果たすものと考えられる。

本論文の要旨は第 40 回日本産科婦人科内視鏡学 会 (東京) で発表した。

\section{参考文献}

1) Takeuchi H, Kuwatsuru R. Laparoscopic myomectomy: indications, surgical technique, and indications. J Am Ass Gynecol Laparosc. In press.

2) 武内裕之 他. 腹腔鏡下筋腫核出術時の手術手技 とその成績. 日産婦内視鏡学会誌. $15: 137-141$ 、 1999.

3 ) Takeuchi H. Comparisson of anesthetic methods for microlaparoscopy in women with unexplained infertility. J Am Ass Gynecol Laparosc. 6: 453-457. 1999.

4) Operative Laparoscopy Study Group (OLSG). Postoperative adhesion development after operative laparoscopy: evaluation at early second look laparoscopy. Fertil Steril. 55: 700-704, 1991.

5 ) American Fertility Society. The American Fertility Society classification of adnexal adhesions, distal tubal occlusion, tubal occlusion secondary to tubal ligation, tubal pregnancies, mullerian anomalies and intrauterine adhesions. Fertil Steril. 49: 944-955, 1988.

6) Berkeley AS et al. Abdominal myomectomy and subsequent fertility. Surg Gynecol Obstet. 156: 319-322, 1983.

7 ) Starks GC. CO2 laser myomectomy in an infertile population. J Reprod Med. 33: 184-186, 1988.

8 ) Tulandi $\mathrm{T}$ et al. Adhesion formation and reproductive outcome after myomectomy and second- look laparoscopy. Obstet Gynecol. 82: 213$215,1993$.

9 ) Nezhat C et al. Laparoscopic myomectomy. Int J Fertil. 36: 275-280, 1991.

10) Hasson HM et al. Laparoscopic myomectomy. Obstet Gynecol. 80: 884-888. 1992.

11) Mais V et al. Prevention of de-novo adhesion formation after laparoscopic myomectomy. A randomized trial to evaluate the effectiveness of an oxidized regenerated absorbable barrier. Hum Reprod. 10. 3133-3135, 1995.

12) Dubbuisson JB et al. Second look after laparoscopic myomectomy. Hum Reprod. 13: 2102-2106, 1998.

13) Luciano A et al. A comparative study of postoperative adhesions following laser surgery by laparoscopy versus laparotomy in the rabbit model. Obstet Gynecol. 74: 220-224, 1989.

14) Lundorff $P$ et al. Adhesion formation after laparoscopic surgery in tubal pregnancy : a randomized versus laparotomy.

15) Igarashi M. Value of myomectomy in the treatment of infertility. Feril Steril. 59: 1331, 1993.

16）武内裕之 他. 腹腔鏡下手術におけるフィブリン 糊の使用経験. 産と婦. 61：1163-1168、1994.

17) Takeuchi $\mathrm{H}$ et al. Reduction of adhesions with fibrin glue after laparoscopic excision of large ovarian endometrioma. J Am Ass Gynecol Laparosc. 3: 575-579, 1996.

18) Takeuchi $\mathrm{H}$ et al. Effect of fibrin glue on post surgical adhesions after uterine or ovarian surgery. J Obstet Gynecol Res. 23:479-484, 1997 